\title{
Definition and temporal evolution of the heat and cold waves over the Spanish Central Plateau from 1961 to 2010
}

\author{
ÁNGEL L. LABAJO and MOISÉS EGIDO \\ Departamento de Física General y de la Atmósfera, Facultad de Ciencias, Universidad de Salamanca, \\ 37008-Salamanca, España \\ Corresponding autor: Moisés Egido; e-mail: moi95@usal.es \\ QUINTÍN MARTÍN \\ Departamento de Estadística, Facultad de Medicina, Universidad de Salamanca, Campus Miguel de Unamuno, \\ Alfonso X el Sabio S/N, 37007-Salamanca, España \\ JUAN LABAJO \\ Grupo de Investigación del Clima, Departamento de Geografía, \\ Universidad Autónoma de Madrid, Ciudad Universitaria de Cantoblanco, 28049-Madrid, España \\ JOSÉ LUIS LABAJO \\ Departamento de Física General y de la Atmósfera, Facultad de Ciencias, Universidad de Salamanca, \\ 37008-Salamanca, España
}

Received November 15, 2013; accepted June 2, 2014

\begin{abstract}
RESUMEN
Se establece el comportamiento temporal de las frecuencias anuales de olas de calor y frío observadas entre 1961 y 2010 en la Meseta Central española y en las dos zonas que se pueden diferenciar en ella. A partir de los datos diarios de anomalías de temperatura se determinan las series de anomalías diarias de temperaturas máxima y mínima para las áreas de trabajo. Se obtienen los valores umbrales de dichas series de anomalías, determinados por los percentiles $\mathrm{P}_{10}$ y $\mathrm{P}_{90}$. Se establece la existencia de ola de calor cuando se observan dos o más días consecutivos en los que las anomalías de temperatura máxima y de temperatura mínima superan, simultáneamente, los valores de los umbrales establecidos por el $\mathrm{P}_{90}$. Se identifican las olas de calor que han afectado a la Meseta Central española, y a las dos subzonas durante el periodo de estudio y se establecen sus frecuencias mensuales y anuales. Asimismo, considerando que existe una ola de frío cuando hay dos o más días consecutivos en que los valores de temperaturas máximas y mínimas diarias son inferiores, simultáneamente, a los umbrales establecidos por el $\mathrm{P}_{10}$, se identifican las olas de frío y se establecen sus frecuencias mensuales y anuales en el periodo de estudio. Los resultados indican que los meses con mayor número de olas de calor entre 1961 y 2010 son mayo ( 25 olas) y junio ( 23 olas). El análisis de tendencia de las series de frecuencias anuales obtenidas indica que existe una tendencia creciente de olas de calor a un nivel de confianza mayor del 99\%. El modelo lineal establece que se ha producido un aumento en la frecuencia de olas de calor en la Meseta Central española del orden de 0.6 olas cada 10 años. En cuanto a las olas de frío, se detectan olas de frío todos los meses del año en número que oscila entre ocho y 16 olas. Los meses con menor número son abril (nueve), julio (ocho) y agosto (nueve), y los meses con mayor número son marzo, mayo, junio y octubre con 16 olas. Los años con mayor número de olas de frío son 1969, 1971 y 1977 con siete casos; en el resto de los años la frecuencia anual está comprendida entre uno y seis. El análisis de tendencia de la serie de frecuencias anuales indica que existe una tendencia decreciente de las olas de frío a un nivel de confianza del $99 \%$. Si se considera un modelo lineal, en la Meseta Central española se ha producido, entre 1961 y 2010 , una disminución de olas de frío del orden de 0.54 olas cada 10 años.
\end{abstract}




\begin{abstract}
The temporal behavior of the annual frequency of heat and cold waves observed between 1961 and 2010 is established for the Spanish Central Plateau and for the two sub-areas in it. The series of daily maximum and minimum temperature anomalies for the working areas were calculated from the daily data concerning temperature anomalies. The thresholds of these series of anomalies, determined by the $\mathrm{P}_{10}$ and $\mathrm{P}_{90}$ percentiles values, were obtained. Heat waves occur when there are two or more consecutive days on which the maximum and minimum temperature anomalies are simultaneously greater than the values of the thresholds obtained for the $\mathrm{P}_{90}$ percentile. The heat waves that affected the Spanish Central Plateau and the two sub-areas during the period of time considered were identified and their monthly and annual frequencies were obtained. Likewise, a cold wave is considered to have occurred when there are two or more consecutive days on which the maximum and minimum temperature anomalies are simultaneously lower than the thresholds established by the corresponding $\mathrm{P}_{10}$ percentiles. The cold waves occurring in the study area were identified and their monthly and annual frequencies in the study period were established. According to the results, the months with highest number of heat waves between 1961 and 2010 were May (25 waves) and June (23 waves). Trend analysis of the series of annual frequencies indicates that there was an increasing trend towards the occurrence of heat waves, with a confidence level greater than $99 \%$. The linear model established indicates that an increase had occurred in the frequency of heat waves in the Spanish plateau of the order of 0.6 waves every 10 years. Regarding cold waves, these were detected in each month of the year and their frequency ranged between eight and 16 events per year. The months with lowest number of cold waves were April (nine), July (eight) and August (nine), and the months with the highest number were March, May, June and October, with 16 cold waves. The years with the highest number of cold waves were 1969, 1971 and 1977, with seven cases. In the other years the annual rate was between one and six. Trend analysis of the series of annual frequencies indicated that there was a decreasing frequency of cold waves, at the confidence level of $99 \%$. When a linear model was considered for the Spanish Central Plateau a decreasing frequency of the cold waves of the order of 0.54 waves in every 10 years was observed from 1961 to 2010 .
\end{abstract}

Keywords: Anomaly, temperature, heat wave, cold wave, frequency, trend.

\section{Introduction}

Extreme atmospheric events, hurricanes, heavy floods, heat and cold waves have always affected the normal development of human activities and produce considerable material damage, affecting people's safety and even leading to the loss of life. In the last two decades, once the behavior of the average values of climate variables had been analyzed, and according to the suggestions made in the last two reports of the IPCC, climate change studies have focused on the behavior of the extreme values of these variables and the associated atmospheric phenomenology (Plummer et al., 1999; Griffiths et al., 2003; Labajo et al., 2004, 2008).

These extreme values of climate variables are associated with extreme weather events, which have been analyzed carefully by many researchers (Brunetti et al., 2001; Labajo et al., 2004, 2006, 2008).

Regarding temperature, studies have been carried out on the temporal behavior of extreme daily values at different spatial scales (Manton et al., 2001; Salinger and Griffiths, 2001). Based on the behavior of the average values of climate variables, and ac- cording to the suggestions of the recent reports of the IPCC (IPCC, 2013), climate change studies are now focusing on the behavior of their extreme values and the associated atmospheric phenomenology (heavy rain, strong winds or very high temperatures in some areas and droughts or very low temperatures in others) (Plummer et al., 1999; Domonkos et al., 2003; Griffiths et al., 2003; Klein and Können, 2003; Ortega et al., 2006; Labajo et al., 2004, 2008), and the conditions for determining the occurrence of extremely warm or cold days have been established (Labajo and Labajo, 2010; Zhou and Ren, 2012).

Special importance has been given to the study of the trends in the frequency of extreme heat and cold events (heat and waves) owing to the impact that extreme temperature events can have on ecosystems, and in particular on human activity (Kysely, 2002; Khaliq et al., 2005; Kysely and Dubrovský, 2005; Baldi et al., 2006).

This work establishes the criterion for considering successions of days with daily minimum and maximum temperatures above or below certain limits, as heat or cold waves from a strictly climatic point of 
view. The temporal behavior of the frequency of heat or cold waves throughout the year in the Spanish Central Plateau and in each of the sub-areas considered (northern and southern sub-plateaus) is analyzed for the period 1961-2010. Finally, we determine their trend and attempt to establish models for the temporal evolution of the annual frequency of heat and cold waves throughout the year.

\section{Study area, data and methodology}

\subsection{Study area}

The study was performed in a broad zone of the Iberian Peninsula, the Spanish Central Plateau, which includes three regions. This zone covers an area between $38^{\circ} 01^{\prime}$ and $43^{\circ} 4^{\prime} \mathrm{N}$, and $0^{\circ} 54^{\prime}$ and $06^{\circ} 07^{\prime} \mathrm{W}$ (Fig. 1), and features continental Mediterranean weather with warm summers and cold winters, where extreme temperature events are detected quite frequently. Two sub-areas with different physical and geographical characteristics can be described in this area, namely the northern sub-plateau and the southern sub-plateau. The average height above sea level of the northern sub-plateau is approximately $800 \mathrm{~m}$ and that of the southern sub-plateau is $600 \mathrm{~m}$, and their climates, even though both are continental Mediterranean, show relatively important differences. Accordingly, a study was carried out for each of the two sub-regions and for the Central Plateau as a whole. Figure 1 depicts the Spanish central Plateau and both sub-plateaus and their locations on continental Spain.

\subsection{Data and methodology}

The data used for this study were provided by the Agencia Estatal de Meteorología (AEMET), Spain's State Meteorological Agency. They represent the daily maximum temperatures and daily minimum temperatures obtained at the observatories in Ávila, Burgos, León, Salamanca, Segovia, Soria, Valladolid (Villanubla), Zamora, located in the northern sub-plateau; and Albacete (Los Llanos), Ciudad Real, Cuenca, Toledo, and Madrid (El Retiro and Barajas), included in the southern sub-plateau during the 1961-2010 period. These observatories were selected because they are main stations of the Spanish synoptic network and the series of climatic variables provided by them have a high degree of reliability. Furthermore, they are distributed in such a way that

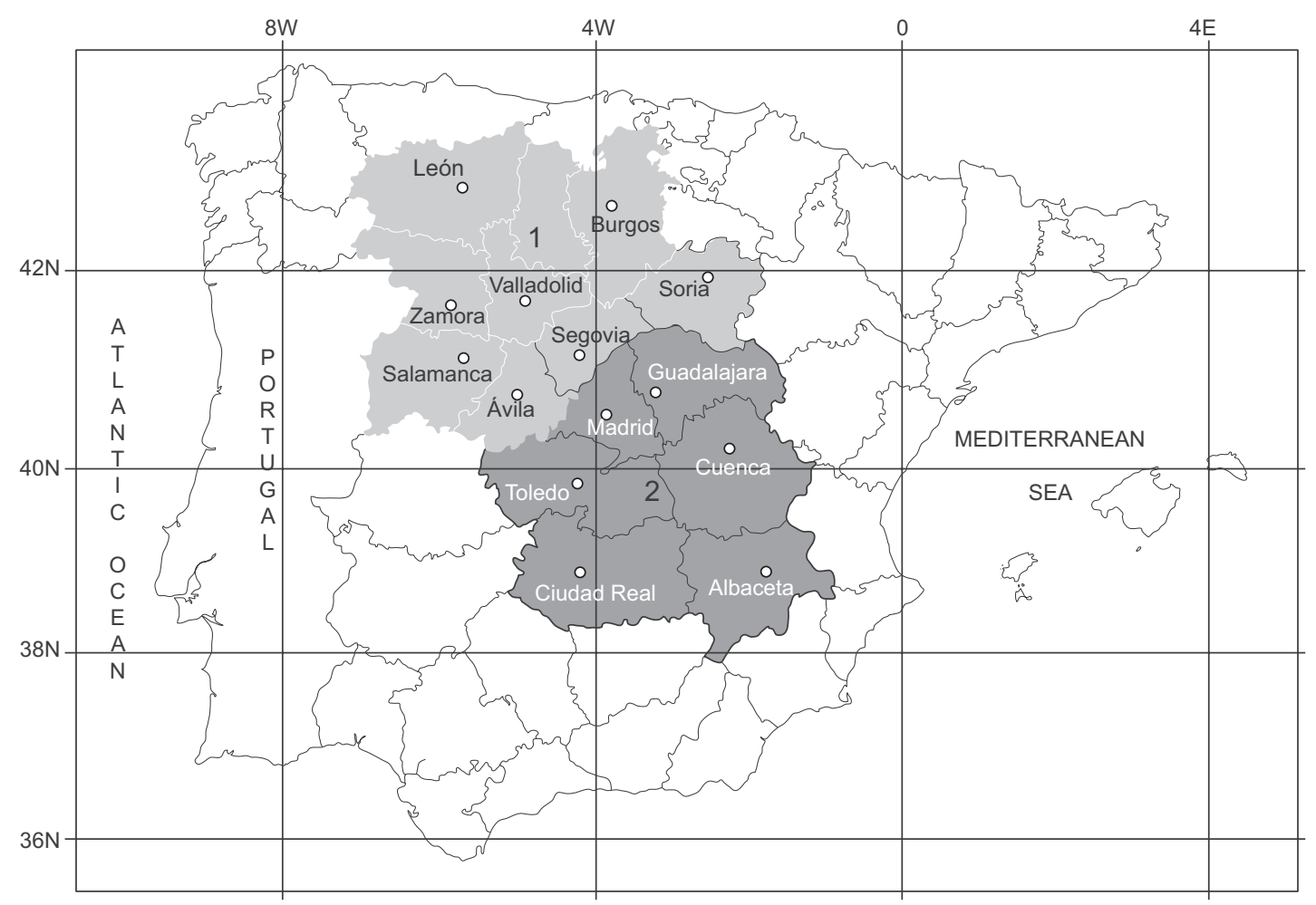

Fig. 1. Study zone. (1) Northern sub-plateau, (2) southern sub-plateau. 
they provide sufficient coverage to consider the results obtained as being significant for the region.

The quality of these series has been checked previously by the AEMET and the reliability of their sources has been confirmed. These series have been also addressed in previous works (Labajo et al., 2004, 2006, 2008, 2012), and formed the initial database of the daily data required for the development of the study.

The series of daily maximum temperatures anomalies (DMATA) and daily minimum temperatures anomalies (DMITA) were obtained from the daily maximum temperature and daily minimum temperature series. Anomalies were obtained as the difference between the daily data of the series and the corresponding mean value obtained for each of the days of the year in the 1961-1990 interval.

The regional DMATA and DMITA series for the Central Plateau and for the two sub-plateaus were calculated from the series of anomalies of the observatories selected using the inverse distance method (Jones and Hulme, 1996). A grid with two sub-grids covering the whole study area was established in order to obtain the regional series. The inverse-of-distance method was applied to the series of initial data from the observatories in each of the regions. Then, the DMATA and DMITA series representative of each of the sub-plateaus were obtained. From these series, the representative DMATA and DMITA series of the Central Plateau were obtained by applying the method to the whole study area. These series were used in the development our work.

We used DMATA and DMITA instead of daily maximum and minimum temperature observational data because for both, seasonality was filtered out and no correction by height of the values measured directly at each of the observatories was necessary (Labajo et al., 2012). In addition, their temporal variability was much lower than that of the original data and facilitated the study along the year, or for the different seasons of the year, without the need to introduce monthly or seasonal restrictions.

From the anomaly series, the extremely warm and extremely cold days were obtained applying the percentile criterion, which is widely used to determine the threshold of extreme values of climate variables (Manton et al., 2001; Salinger and Griffiths, 2001; DeGaetano and Allen, 2002; Griffiths et al., 2003; Labajo et al., 2004, 2006, 2008). A day was considered as extremely warm when the corresponding DMATA and DMITA were simultaneously greater than the threshold value defined by a certain percentile $\left(\mathrm{P}_{90}\right.$, $\left.\mathrm{P}_{95}, \mathrm{P}_{99}\right)$ in both series, and was considered as extremely cold when those values were simultaneously below the threshold defined by the other percentile values $\left(\mathrm{P}_{10}, \mathrm{P}_{05}, \mathrm{P}_{01}\right)$ taken into account (Labajo and Labajo, 2010).

Normally, a day is considered as extremely warm or cold when the maximum or minimum temperature is greater or lower than the average value of the variable. This may seem sufficient for the definition of warm or cold days. However, if only this criterion is considered, a day with a very high maximum temperature but with a very low minimum temperature could be considered as an extremely warm day and extremely cold day at the same time, whereas in fact it would have a normal average temperature. Such days should not be defined as warm or cold days. This situation may be slightly more frequent in the warm season with cold waves, and in the cold season with heat waves. Accordingly, the maximum and minimum temperature values should be taken into account simultaneously in order to define a day as extremely warm or extremely cold, as described above.

In a previous work, the percentiles chosen to obtain extremely warm days (EWD) or extremely cold days (ECD) were $\mathrm{P}_{95}$ and the $\mathrm{P}_{05}$, respectively (Labajo et al. 2004, 2006, 2008, 2012). These percentile values were chosen according to the definition of the "trimmed mean" statistical variable, which is defined as the average of several values after the most extreme values $(5 \%$ of the highest and lowest values, the tails of the empirical probability distribution) have been removed. This characteristic is considered to be more representative to the climatic mean than the arithmetic average of the series. Here, however, to determine heat or cold waves it might be too restrictive to use the $\mathrm{P}_{95}$ and $\mathrm{P}_{05}$ DMATA and DMITA values from each of the series as the threshold. We therefore consider the thresholds for $\mathrm{P}_{90}$ and $\mathrm{P}_{10}$ of all the series and used the thresholds defined by $\mathrm{P}_{95}$ and $\mathrm{P}_{05}$ to determine the cases of intense heat or cold waves.

According to Robinson (2001), currently there is no strict definition of warm and cold waves. Normal$1 y$, this extreme phenomenon is not only associated with the values of meteorological variables - especially temperature - but also with the effects on 
ecosystems (Changnon et al., 2003; Khalio et al., 2005; Nogueira and Paixao, 2008). Lopez-Díaz (2004) studied the behavior of heat waves using only long temperature series obtained at several observatories in peninsular Spain, and highlighted the difficulties involved in determining their trend, including the need to use the threshold variable. Thus, heat waves are commonly studied in the warm period of the year and cold waves in the cold period, although they can be observed throughout the year. In our study, the warm period includes the months of June, July, August and September, while the cold period includes November, December, January and February.

Table I shows the threshold values determined by the 95, 90, 10 and 05 percentiles for the whole year (complete series) and for both periods (the warm and the cold periods). The threshold values were obtained by calculating the percentiles with statistics software
(SPSS). As can be seen in Table I, there were only small differences between the percentiles of the cold and warm periods and those corresponding to the complete year. Thus, the percentiles of the whole year could be used as thresholds for studying the warm and cold periods at any time of the year.

From these thresholds, the EWD and the ECD on the Spanish Central Plateau, and on the two sub-plateaus were obtained for the period examined. An EWD was considered to be a day on which the DMATA and DMITA values were simultaneously greater than the thresholds established with $\mathrm{P}_{90}$. If the DMATA and DMITA values were simultaneously greater than the thresholds established with $\mathrm{P}_{95}$, then the day was considered an intense EWD. Likewise an ECD was considered when the DMATA and DMITA values were simultaneously lower than the thresholds determined by $\mathrm{P}_{10} . \mathrm{P}_{05}$ was considered as a threshold for intense ECD events.

Table I. Threshold DMATA and DMITA values, determined with the $\mathrm{P}_{05}, \mathrm{P}_{10}$ and $\mathrm{P}_{90}, \mathrm{P}_{95}$ percentiles on the Central Plateau and both subplateaus in each period of the year and throughout the year.

\begin{tabular}{llccc}
\hline & & $\begin{array}{c}\text { Northern } \\
\text { sub-plateau }\end{array}$ & $\begin{array}{c}\text { Southern } \\
\text { sub-plateau }\end{array}$ & $\begin{array}{c}\text { Central } \\
\text { Plateau }\end{array}$ \\
\hline \multirow{3}{*}{$\mathrm{P}_{05}$ DMATA } & Cold period & -5.45 & -5.07 & -5.03 \\
& Warm period & -6.78 & -6.45 & -6.62 \\
& Year & -6.28 & -6.10 & -6.11 \\
\hline \multirow{3}{*}{$\mathrm{P}_{05}$ DMITA } & Cold period & -5.38 & -5.38 & -5.13 \\
& Warm period & -4.58 & -3.98 & -4.16 \\
& Year & -5.02 & -4.75 & -4.73 \\
\hline \multirow{3}{*}{$\mathrm{P}_{10}$ DMATA } & Cold period & -4.21 & -3.86 & -3.91 \\
& Warm period & -5.41 & -5.01 & -5.13 \\
& Year & -5.00 & -4.76 & -4.79 \\
\hline \multirow{3}{*}{$\mathrm{P}_{10}$ DMITA } & Cold period & -4.32 & -4.40 & -4.17 \\
& Warm period & -3.51 & -3.04 & -3.18 \\
& YEAR & -3.98 & -3.69 & -3.68 \\
\hline \multirow{3}{*}{$\mathrm{P}_{90}$ DMATA } & Cold period & 4.15 & 3.83 & 3.87 \\
& Warm period & 5.32 & 4.48 & 4.81 \\
& Year & 5.22 & 4.70 & 4.81 \\
\hline \multirow{3}{*}{$\mathrm{P}_{90}$ DMITA } & Cold period & 4.54 & 4.47 & 4.28 \\
& Warm period & 3.53 & 3.14 & 3.19 \\
& Year & 3.99 & 3.73 & 3.71 \\
\hline \multirow{2}{*}{$\mathrm{P}_{95}$ DMATA } & Cold period & 5.27 & 4.94 & 4.91 \\
& Warm period & 6.52 & 5.51 & 5.87 \\
& Year & 6.51 & 5.93 & 6.03 \\
\hline \multirow{2}{*}{ DMITA } & Cold period & 5.63 & 5.61 & 5.34 \\
& Warm period & 4.52 & 3.89 & 4.03 \\
& Year & 5.07 & 4.69 & 4.64 \\
\hline & & & & \\
\hline
\end{tabular}


The corresponding annual frequencies series were built from the results obtained. These frequency series allowed us to establish the annual frequencies of heat and cold waves in the entire study area and in the two subzones.

Definition of heat wave: Studying the temporal behavior of the annual frequency of heat waves requires a definition based on the same climatic variables throughout the year, regardless of the effects on ecosystems. The variables considered here were DMATA and DMITA. A heat wave was considered to have occurred when both variables were simultaneously higher than the thresholds determined by the 90th percentile for at least two consecutive days. The thresholds considered were those corresponding to the complete DMATA and DMITA series, disregarding the seasonal variations in their probability distribution.

The heat waves separated by an interval of one day were considered to belong to the same wave when either of the two variables, DMATA or DMITA, exceeded its threshold on that intermediate day; in this case, the length of the unified heat wave was the total number of days, from the first day of the first heat wave until the last day of the second heat wave. Similarly, the annual frequency series of the most intense heat waves was established from the threshold values determined by the 95 th percentile of the empirical probability distribution.

Definition of cold wave: As in the case of the heat waves, a cold wave was considered to have occurred when the DMATA and DMITA were simultaneously lower than the threshold values determined by $\mathrm{P}_{10}$ for at least two consecutive days.

Two or more consecutive cold waves separated by an interval of one day were considered to belong to the same wave when on this day one of the two variables, DMATA or DMITA, had a lower value than the corresponding threshold; in this case the length of the wave was the total number of days of the consecutive cold waves, including the intermediate days. In the same way, the annual series of frequencies of the intense cold waves were established using the threshold values determined by $\mathrm{P}_{05}$.

With these definitions we constructed the annual frequency series of heat and cold waves detected along the year for the Spanish Central Plateau and the northern and southern sub-plateaus. We developed software which assured that the heat and cold waves detected all parts of the year within the period examined.
This software, which is relatively complicated, also allowed us to determine the length of the heat and cold waves and provided us with their monthly and annual frequencies as well as the corresponding dates. These annual frequency series of heat and cold waves were analyzed to establish their distribution along the year, their lengths, and their possible temporal trends. Finally, we analyzed the temporal behavior of these frequencies using linear models.

\section{Results}

\subsection{Heat waves}

According to the definition of heat wave, from the EWD series established by the thresholds corresponding to $\mathrm{P}_{90}$ and $\mathrm{P}_{95}$, respectively, we identified the heat waves and their lengths along each year of the period considered. We then built the series of annual frequencies in each case for the period considered regardless of the length of the waves.

The annual frequency series of heat waves allowed us to establish their temporal distribution (shown in Fig. 2) in the areas under study. On the Spanish Central Plateau the year with the highest frequency of heat waves $\left(\mathrm{P}_{90}\right)$ was 2005 (eight) followed by 2006 and 2009 (seven). In the case of the most intense heat waves $\left(\mathrm{P}_{95}\right)$, the years with the highest frequency were 1964, 2007 and 2009. In 1964, all the waves detected were intense. The total number of heat waves was 124, of which 64 were intense.

On the northern sub-plateau, the total number of heat waves detected between 1961 and 2010 was 127 , of which 44 were intense. The year with the highest frequency (eight) was 2003, when also the highest frequency of intense heat waves (four) was observed.

On the southern sub-plateau, 98 heat waves were detected, of which 29 were intense. The highest annual frequencies were observed in 2005 (nine) and 2006 (eight). The highest frequency of the most intense heat waves (six) was observed for 2009.

The total number of heat waves detected for the period 1961-2010 for the northern sub-plateau was greater than for the southern sub-plateau. This could be due to the physical and geographical differences between both regions.

The heat wave distribution in each month of the year on the Central Plateau and on both sub-plateaus is shown in Table II, whose results demonstrate that according to the definition used in this study there were heat waves in the study areas in each month 

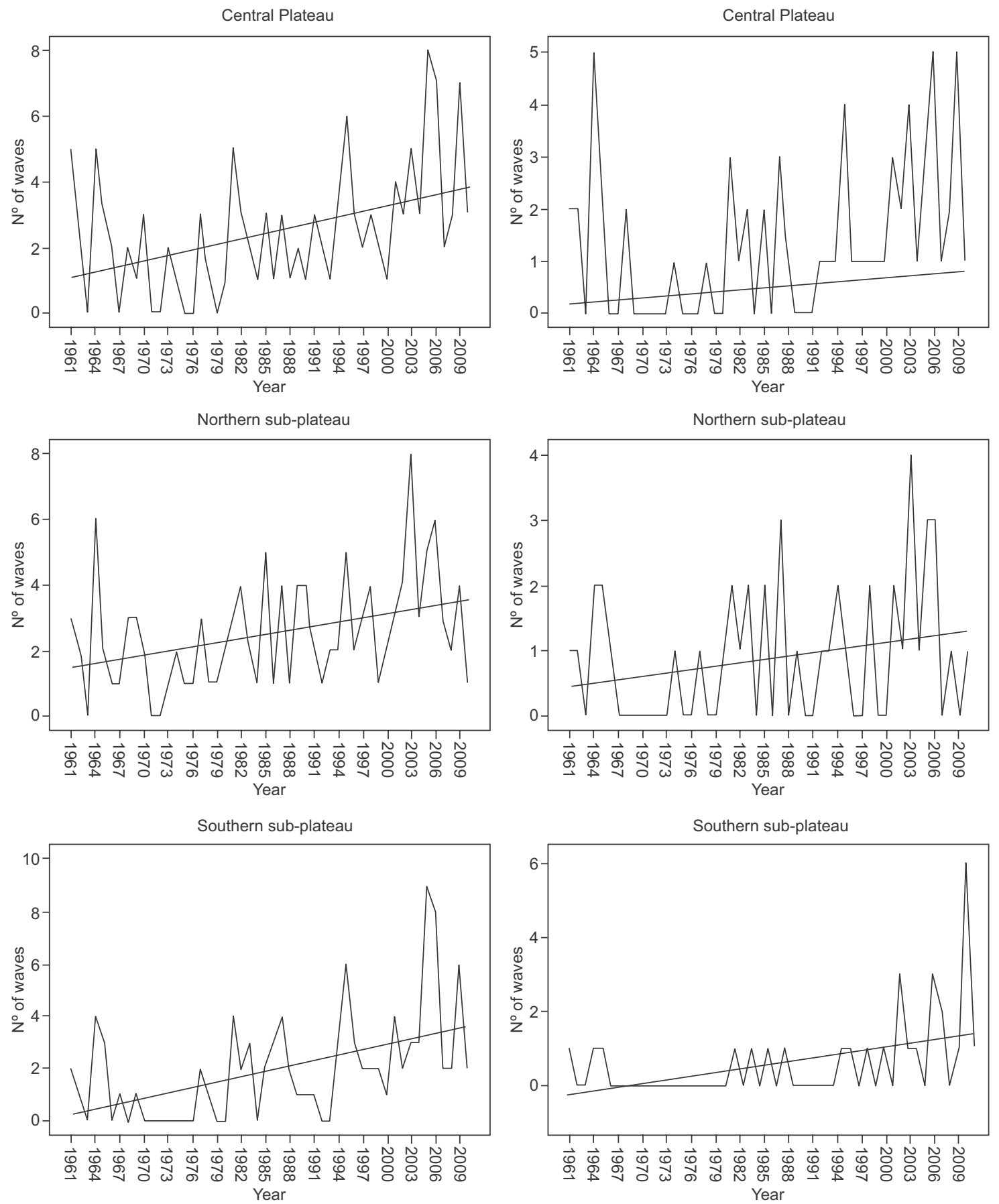

Fig. 2. Temporal evolution of the annual frequency of heat waves $\left(\mathrm{P}_{90}\right)$, and most intense heat waves $\left(\mathrm{P}_{95}\right)$ on the Spanish Central Plateau and the two sub-plateaus during 1961-2010.

of the year. The months with the highest number of heat waves $\left(\mathrm{P}_{90}\right)$ on the Spanish Central Plateau and on the two sub-plateaus were May and June, but a large number of heat waves were also detected in April and August, except for August on the southern sub-plateau.
During the period considered, except for the months of January, February, and November, the number of monthly heat waves detected was six or more.

The frequency distribution of intense heat waves $\left(\mathrm{P}_{95}\right)$ followed the same temporal pattern, and thus the months with the highest number of events were 
Table II. Total number of heat waves in each month detected for the $\mathrm{P}_{90}$ and $\mathrm{P}_{95}$ thresholds in the 1961-2010 period.

\begin{tabular}{lccccrrrrrrrrr}
\hline & & Jan & Feb & Mar & Apr & May & Jun & Jul & Aug & Sept & Oct & Nov & Dec \\
\hline Central & $\mathbf{P}_{\mathbf{9 0}}$ & $\mathbf{1}$ & $\mathbf{3}$ & $\mathbf{9}$ & $\mathbf{1 4}$ & $\mathbf{2 5}$ & $\mathbf{2 3}$ & $\mathbf{8}$ & $\mathbf{1 4}$ & $\mathbf{8}$ & $\mathbf{8}$ & $\mathbf{3}$ & $\mathbf{8}$ \\
Plateau & $\mathrm{P}_{95}$ & 0 & 2 & 2 & 8 & 18 & 16 & 2 & 4 & 4 & 4 & 2 & 2 \\
\hline Northern & $\mathbf{P}_{\mathbf{9 0}}$ & $\mathbf{5}$ & $\mathbf{2}$ & $\mathbf{9}$ & $\mathbf{1 5}$ & $\mathbf{2 1}$ & $\mathbf{1 7}$ & $\mathbf{1 1}$ & $\mathbf{1 6}$ & $\mathbf{1 1}$ & $\mathbf{7}$ & $\mathbf{3}$ & $\mathbf{1 0}$ \\
sub-plateau & $\mathrm{P}_{95}$ & 0 & 0 & 4 & 3 & 9 & 8 & 3 & 6 & 4 & 2 & 1 & 4 \\
\hline Southern & $\mathbf{P}_{\mathbf{9 0}}$ & $\mathbf{1}$ & $\mathbf{1}$ & $\mathbf{6}$ & $\mathbf{1 1}$ & $\mathbf{2 3}$ & $\mathbf{2 3}$ & $\mathbf{7}$ & $\mathbf{4}$ & $\mathbf{4}$ & $\mathbf{7}$ & $\mathbf{3}$ & $\mathbf{8}$ \\
sub-plateau & $\mathrm{P}_{95}$ & 0 & 0 & 1 & 3 & 11 & 10 & 0 & 0 & 0 & 2 & 2 & 0 \\
\hline
\end{tabular}

May and June. The length of the heat waves observed on both the Central Plateau and the two sub-plateaus varied across a relatively large interval (from two to more than 10 days). The total number of heat waves of a certain length detected in the period considered is shown in Table III. In the whole study area, and in both sub-areas, the most frequent heat wave duration varied between two and four days. The longest heat waves were observed on the Central Plateau (two waves lasting 11 days) and on the southern sub-plateau (one wave lasting 16 days). On the northern sub-plateau the maximum heat wave length detected was eight days.

As in the case of the monthly distribution, the distribution of the lengths of intense heat waves is similar to that of all heat waves, but their maximum length was only six days on both sub-plateaus.

The plots in Figure 2 show the trend lines established with a linear model. Both in the general case and for the intense heat waves, the plots show an increasing trend. To determine the significance of these trends, at least at confidence levels of 90 and 95\%, Spearman's rho $\left(r_{s}\right)$ non-parametric trend test and Kendall's tau-b $\left(r_{t}\right)$ (Sneyers, 1975) were applied for the two series of the annual frequencies of heat waves. The results are shown in Table IV.
The results of Table IV indicate that the annual frequency of heat waves and intense heat waves on the Spanish Central Plateau and the two sub-plateaus has increased at a very high confidence level (significance level $\alpha<0.01$ ). In the case of intense waves, in the northern sub-plateau no trend was detected at the level of confidence considered.

\subsection{Cold waves}

Regarding cold waves, we established the annual frequency series detected throughout the area and sub-areas under study, using the same methodology as for the heat waves. The temporal distribution of cold waves can be established from their annual frequencies. This distribution is shown in Figure 3.

The annual frequency of cold waves on the Spanish Central Plateau ranged from zero to seven, with the maximum number of events in 1969, 1971 and 1977 and the minimum number of events in 1968 and 1989. The most intense cold waves had their maximum annual frequency (four cases) in 1971 and 1984. The total number of cold waves from 1961 to 2010 was 150, of which 56 were intense cold waves.

On the northern sub-plateau, the total number of cold waves detected was 168 , and the total number

Table III. Distribution of heat waves according to their duration (1961-2010).

\begin{tabular}{lcrrrrrrrrrr}
\hline & \multicolumn{8}{c}{ Duration of heat waves (number of days) } \\
\cline { 2 - 12 } & & 2 & 3 & 4 & 5 & 6 & 7 & 8 & 9 & 10 & $>10$ \\
\hline Central Plateau & $\mathbf{P}_{\mathbf{9 0}}$ & $\mathbf{4 9}$ & $\mathbf{3 7}$ & $\mathbf{1 8}$ & $\mathbf{6}$ & $\mathbf{6}$ & $\mathbf{2}$ & $\mathbf{1}$ & $\mathbf{2}$ & $\mathbf{1}$ & $\mathbf{2}$ \\
Number of events & $\mathrm{P}_{95}$ & 31 & 18 & 7 & 2 & 4 & 2 & 1 & 0 & 1 & 0 \\
\hline Northern sub-plateau & $\mathbf{P}_{\mathbf{9 0}}$ & $\mathbf{5 7}$ & $\mathbf{3 2}$ & $\mathbf{2 0}$ & $\mathbf{7}$ & $\mathbf{4}$ & $\mathbf{4}$ & $\mathbf{3}$ & $\mathbf{0}$ & $\mathbf{0}$ & $\mathbf{0}$ \\
Number of events & $\mathrm{P}_{95}$ & 19 & 15 & 5 & 3 & 2 & 0 & 0 & 0 & 0 & 0 \\
\hline Southern sub-plateau & $\mathbf{P}_{\mathbf{9 0}}$ & $\mathbf{4 8}$ & $\mathbf{2 4}$ & $\mathbf{1 2}$ & $\mathbf{3}$ & $\mathbf{5}$ & $\mathbf{2}$ & $\mathbf{2}$ & $\mathbf{1}$ & $\mathbf{0}$ & $\mathbf{1}$ \\
Number of events & $\mathrm{P}_{95}$ & 19 & 5 & 2 & 2 & 1 & 0 & 0 & 0 & 0 & 0 \\
\hline
\end{tabular}


Table IV. Trends of annual frequencies of heat waves $\left(\mathrm{P}_{90}\right)$, and of the most intense heat waves $\left(\mathrm{P}_{95}\right)$ in the 1961-2010 period.

\begin{tabular}{|c|c|c|c|c|c|}
\hline \multicolumn{6}{|c|}{ Spearman's rho } \\
\hline & & $r_{s}$ & $\begin{array}{c}\text { Significance } \\
\alpha\end{array}$ & $\begin{array}{l}\text { No. } \\
\text { of data }\end{array}$ & Trend \\
\hline Central & $\mathbf{P}_{90}$ & 0.417 & $\mathbf{0 . 0 0 3}^{\text {*** }}$ & 50 & I \\
\hline Plateau & $\mathrm{P}_{95}$ & 0.371 & $0.008^{* *}$ & 50 & I \\
\hline Northern & $\mathbf{P}_{90}$ & 0.360 & $0.010 *$ & 50 & I \\
\hline sub-plateau & $\mathrm{P}_{95}$ & 0.206 & 0.152 & 50 & $\mathrm{~N}$ \\
\hline Southern & $\mathbf{P}_{90}$ & 0.502 & $<10^{-3 * *}$ & 50 & I \\
\hline sub-plateau & $\mathrm{P}_{95}$ & 0.421 & $0.002^{* *}$ & 50 & I \\
\hline \multicolumn{6}{|c|}{ Kendall's Tau-b } \\
\hline & & $r_{t}$ & $\begin{array}{c}\text { Significance } \\
\alpha\end{array}$ & $\begin{array}{c}\text { No. } \\
\text { of data }\end{array}$ & Trend \\
\hline Central & $\mathbf{P}_{90}$ & 0.321 & $0.002^{* * *}$ & 50 & I \\
\hline Plateau & $\mathrm{P}_{95}$ & 0.305 & $0.005^{* * *}$ & 50 & I \\
\hline \multirow{2}{*}{$\begin{array}{l}\text { Northern } \\
\text { sub-plateau }\end{array}$} & $\mathbf{P}_{90}$ & 0.275 & $0.009^{* * *}$ & 50 & I \\
\hline & $\mathrm{P}_{95}$ & 0.162 & 0.141 & 50 & $\mathrm{~N}$ \\
\hline \multirow{2}{*}{$\begin{array}{l}\text { Southern } \\
\text { sub-plateau }\end{array}$} & $\mathbf{P}_{90}$ & 0.364 & $0.001^{* *}$ & 50 & I \\
\hline & $\mathrm{P}_{95}$ & 0.340 & $0.003^{* *}$ & 50 & I \\
\hline
\end{tabular}

* Significant correlation at the (bilateral) 0.05 level $\left(r_{s}\right.$ : Spearman's correlation coefficient; $\alpha$ : level of significance; I: Significant increasing trend; N: No significant trend detected)

** Correlation significant at the 0.01 (bilateral) level.

of intense cold waves was 63 . The annual frequency of cold waves ranged between zero and nine. The years with the highest frequencies of cold waves were 1971 (nine waves) and 1984 (eight waves). In the case of the intense cold waves, the years with the highest frequency (four waves) were 1984 and 2010.

On the southern sub-plateau, 131 cold waves were detected, of which 44 were intense cold waves. Their annual frequency ranged from zero to eight. The years with the highest frequency (eight waves) were 1977 and 1984. The intense cold waves had the highest frequency (four waves) in 1971.

The frequency distribution of the cold waves detected for each month of the year on the Spanish Central Plateau and on each of the two sub-plateaus is shown in Table $\mathrm{V}$.

The results shown in Table $\mathrm{V}$ indicate that the distribution of cold waves throughout the year was fairly uniform on both the Spanish Central Plateau and the two sub-plateaus. The number of cold waves in each month of the year was different on the Central Plateau and in each of the two sub-plateaus. On the Central Plateau, the highest number of cold waves was detected in March, May, June and October, while on the northern sub-plateau, the months with the highest number of cold waves were September and February, and on the southern sub-plateau the highest number of cold waves was seen in February, March, May and June.

The number of cold waves detected for the period 1961-2010 was higher in each month on the northern sub-plateau than on the southern sub-plateau except for August and October. This difference can be explained, as in the case of heat waves, by the different physical and geographical features of the regions examined. On the Spanish Central Plateau, the monthly frequencies of cold waves lay between the frequencies obtained for both sub-plateaus. The monthly distribution of cold waves and intense cold waves shows a similar type of behavior.

According to the criteria established to define them, the length of the cold waves detected on the Spanish Central Plateau and the southern sub-plateau ranged between two and more than 10 days. On the northern sub-plateau this length ranged between two and 10 days. Table VI depicts the distribution of the cold waves according to their lengths.

Concerning the main area and the two subzones under study, most of the cold waves detected (49, 45 and $46 \%$, respectively) lasted two days. The waves lasting longer than four days represented only $11 \%$ of the total cases on the Central Plateau, and 10\% on the two sub-plateaus. The two longest cold waves lasted 13 days and were recorded from December 23, 1970 to January 4, 1971 and from May 5, 1984 to May 23, 1984 on the Central Plateau, together with one cold wave of 10 days recorded from December 26, 1970 to January 4, 1971 on the northern sub-plateau, and one cold wave of 15 days recorded from December 24, 1970 to January 7, 1971 on the southern sub-plateau.

The plots for the temporal distribution of the annual frequency of cold waves (Fig. 3) include the trend lines considering a linear model. A decreasing trend in the frequency of both cold waves and intense cold waves on the Spanish Central Plateau can be seen. To check the significance of the trend, at least 

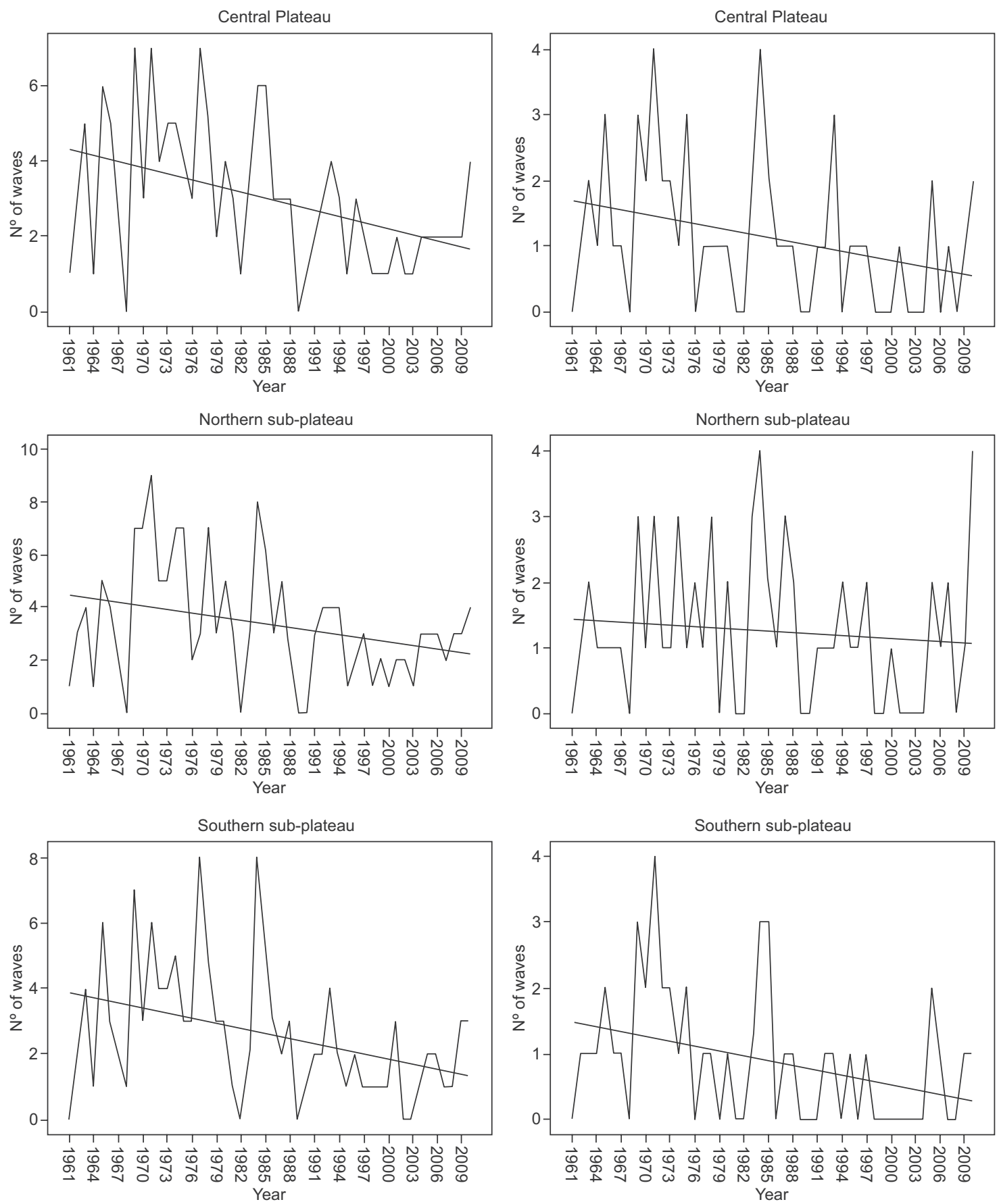

Fig. 3. Temporal evolution of the annual frequency of cold waves $\left(\mathrm{P}_{10}\right)$, and intense cold waves $\left(\mathrm{P}_{05}\right)$ on the Spanish Central Plateau and the two sub-plateaus for the period 1961-2010.

at a confidence level of $95 \%$ (with which the linear model could serve as a prognostic model), we applied the Spearman and Kendall (Sneyers, 1975) tests to the series of frequencies of cold waves $\left(\mathrm{P}_{10}\right)$ and most intense cold waves $\left(\mathrm{P}_{05}\right)$. The results obtained are shown in Table VII.
The results of Table II indicate that the annual frequency of cold waves on the Spanish Central Plateau and the southern sub-plateau showed a significant decreasing trend at a very high confidence level ( $>99 \%$ ) during the period analyzed. The intense cold waves had the same characteristics but at a 
Table V. Total number of cold waves detected for the threshold values of $\mathrm{P}_{10}$ and $\mathrm{P}_{05}$ in each month for the 1961-2010 period.

\begin{tabular}{lcrrrrrrrrrrrr}
\hline & & Jan & Feb & Mar & Apr & May & Jun & Jul & Aug & Sept & Oct & Nov & Dec \\
\hline Central & $\mathbf{P}_{\mathbf{1 0}}$ & $\mathbf{1 1}$ & $\mathbf{1 4}$ & $\mathbf{1 6}$ & $\mathbf{9}$ & $\mathbf{1 6}$ & $\mathbf{1 6}$ & $\mathbf{8}$ & $\mathbf{9}$ & $\mathbf{1 5}$ & $\mathbf{1 6}$ & $\mathbf{1 0}$ & $\mathbf{1 0}$ \\
Plateau & $\mathrm{P}_{05}$ & 4 & 7 & 8 & 4 & 7 & 6 & 3 & 0 & 9 & 4 & 0 & 4 \\
\hline Northern & $\mathbf{P}_{\mathbf{1 0}}$ & $\mathbf{1 3}$ & $\mathbf{1 8}$ & $\mathbf{1 7}$ & $\mathbf{1 1}$ & $\mathbf{1 7}$ & $\mathbf{1 6}$ & $\mathbf{1 0}$ & $\mathbf{9}$ & $\mathbf{2 0}$ & $\mathbf{1 3}$ & $\mathbf{1 2}$ & $\mathbf{1 2}$ \\
sub-plateau & $\mathrm{P}_{05}$ & 9 & 11 & 6 & 4 & 5 & 7 & 3 & 2 & 4 & 4 & 2 & 6 \\
\hline Southern & $\mathbf{P}_{\mathbf{1 0}}$ & $\mathbf{8}$ & $\mathbf{1 4}$ & $\mathbf{1 4}$ & $\mathbf{9}$ & $\mathbf{1 4}$ & $\mathbf{1 4}$ & $\mathbf{6}$ & $\mathbf{1 0}$ & $\mathbf{1 2}$ & $\mathbf{1 3}$ & $\mathbf{7}$ & $\mathbf{1 0}$ \\
sub-plateau & $\mathrm{P}_{05}$ & 5 & 7 & 5 & 2 & 6 & 6 & 3 & 0 & 5 & 2 & 0 & 3 \\
\hline
\end{tabular}

Table VI. Distribution of cold waves by length (1961-2010).

\begin{tabular}{lcrrrrrrrrrc}
\hline & \multicolumn{10}{c}{ Length of cold waves (number of days) } \\
\cline { 2 - 12 } & & 2 & 3 & 4 & 5 & 6 & 7 & 8 & 9 & 10 & $>10$ \\
\hline Central Plateau & $\mathbf{P}_{\mathbf{9 0}}$ & $\mathbf{7 3}$ & $\mathbf{3 9}$ & $\mathbf{2 1}$ & $\mathbf{6}$ & $\mathbf{4}$ & $\mathbf{1}$ & $\mathbf{1}$ & $\mathbf{3}$ & $\mathbf{0}$ & $\mathbf{2}$ \\
Number of events & $\mathrm{P}_{95}$ & 27 & 16 & 6 & 3 & 2 & 1 & 0 & 1 & 0 & 0 \\
\hline Northern sub-plateau & $\mathbf{P}_{\mathbf{9 0}}$ & $\mathbf{7 5}$ & $\mathbf{6 1}$ & $\mathbf{1 5}$ & $\mathbf{6}$ & $\mathbf{3}$ & $\mathbf{3}$ & $\mathbf{2}$ & $\mathbf{2}$ & $\mathbf{1}$ & $\mathbf{0}$ \\
Number of events & $\mathrm{P}_{95}$ & 40 & 12 & 6 & 2 & 0 & 2 & 0 & 1 & 0 & 0 \\
\hline Southern sub-plateau & $\mathbf{P}_{\mathbf{9 0}}$ & $\mathbf{6 6}$ & $\mathbf{3 5}$ & $\mathbf{1 5}$ & $\mathbf{7}$ & $\mathbf{3}$ & $\mathbf{1}$ & $\mathbf{1}$ & $\mathbf{2}$ & $\mathbf{0}$ & $\mathbf{1}$ \\
Number of events & $\mathrm{P}_{95}$ & 27 & 8 & 3 & 3 & 1 & 2 & 0 & 0 & 0 & 0 \\
\hline
\end{tabular}

lower significance level. On the northern sub-plateau there was no trend at the minimum confidence level considered (95\%), although the signs of the Spearman and Kendall correlation coefficients indicated a decreasing trend for lower levels of confidence.

\subsection{Linear trend models}

The results obtained by applying the Spearman test to the annual frequencies of heat and cold waves allowed us to consider the possibility of establishing a linear model of temporal behavior in both cases. For the temporal trend of the annual frequency of heat waves $[F r(H)]$ on the Spanish Central Plateau, for the 1961-2010 period and considering one year as the unit of time, the equation defining the linear model would be:

$$
\operatorname{Fr}(H)=0.056 \times \text { year }-1.052
$$

This linear model indicates a possible increase in the annual frequency of heat waves in the study area of the order of 0.6 waves per decade.

The linear model for the temporal behavior of annual frequency $[\operatorname{Fr}(C)]$ of cold waves on the
Spanish Central Plateau for the period 1961-2010 is defined by:

$\operatorname{Fr}(C)=-0.054 \times$ year +4.367

In this case, the linear model indicated that there was a decreasing trend in the frequency of cold waves of the order of 0.5 waves per decade between 1961-2010.

\section{Conclusions}

Throughout this study we have reported results that allow us to draw the following conclusions:

The total numbers of heat waves detected on the Spanish Central Plateau and on the northern and southern sub-plateaus for the period 1961-2010 according to the established criteria were 124, 127 and 98 , respectively, of which 66,44 and 29, respectively, were intense heat waves. In the case of cold waves, the total numbers of events detected were 150 on the Central Plateau, 168 on the northern sub-plateau, and 131 on the southern sub-plateau, of which 56,63 and 44 , respectively were cold waves.

The variability in the annual frequency of heat and cold waves is relatively large and ranges between 
Table VII. Trends of the annual frequencies of cold waves $\left(\mathrm{P}_{10}\right)$, and intense cold waves $\left(\mathrm{P}_{05}\right)$ for the period 1961-2010.

\begin{tabular}{lccccc}
\hline Spearman's rho & \multicolumn{5}{l}{} \\
\hline & & $r_{s}$ & $\begin{array}{c}\text { Significance } \\
\alpha\end{array}$ & $\begin{array}{c}\text { Number } \\
\text { of data }\end{array}$ & Trend \\
\hline Central & $\mathbf{P}_{\mathbf{1 0}}$ & $-\mathbf{0 . 4 1 9}$ & $\mathbf{0 . 0 0 2}^{* *}$ & $\mathbf{5 0}$ & $\mathbf{D}$ \\
Plateau & $\mathrm{P}_{05}$ & -0.320 & $0.023^{* *}$ & 50 & $\mathrm{D}$ \\
\hline Northern & $\mathbf{P}_{\mathbf{1 0}}$ & $\mathbf{- 0 . 2 7 3}$ & $\mathbf{0 . 0 5 5}$ & $\mathbf{5 0}$ & NT \\
sub-plateau & $\mathrm{P}_{05}$ & -0.128 & 0.376 & 50 & NT \\
\hline Southern & $\mathbf{P}_{10}$ & $-\mathbf{0 . 3 7 3}$ & $\mathbf{0 . 0 0 8}^{* *}$ & $\mathbf{5 0}$ & D \\
sub-plateau & $\mathrm{P}_{05}$ & -0.375 & $0.007^{* *}$ & 50 & D \\
\hline
\end{tabular}

Kendall's tau b

\begin{tabular}{lccccc}
\hline & & $r_{t}$ & $\begin{array}{c}\text { Significance } \\
\alpha\end{array}$ & $\begin{array}{c}\text { Number } \\
\text { of data }\end{array}$ \\
\hline Central & $\mathbf{P}_{\mathbf{1 0}}$ & $\mathbf{- 0 . 3 1 3}$ & $\mathbf{0 . 0 0 3}^{* *}$ & $\mathbf{5 0}$ & $\mathbf{D}$ \\
Plateau & $\mathrm{P}_{05}$ & -0.250 & $0.021^{*}$ & 50 & $\mathrm{D}$ \\
\hline Northern & $\mathbf{P}_{\mathbf{1 0}}$ & $-\mathbf{0 . 1 8 5}$ & $\mathbf{0 . 0 7 3}$ & $\mathbf{5 0}$ & NT \\
sub-plateau & $\mathrm{P}_{05}$ & -0.098 & 0.367 & 50 & NT \\
\hline Southern & $\mathbf{P}_{\mathbf{1 0}}$ & $-\mathbf{0 . 2 8 0}$ & $\mathbf{0 . 0 0 7}^{* *}$ & $\mathbf{5 0}$ & $\mathbf{D}$ \\
sub-plateau & $\mathrm{P}_{05}$ & -0.286 & $0.010^{* *}$ & 50 & $\mathrm{D}$ \\
\hline
\end{tabular}

* Significant correlation at the (bilateral) 0.05 level $\left(r_{s}\right.$ : Spearman's correlation coefficient; $\alpha$ : level of significance; D: Significant decreasing trend; N: Nosignificant trend at the level considered).

** Correlation significant at the 0.01 (bilateral) level.

zero and eight for heat waves and between zero and seven for cold waves. In the case of heat waves, the highest annual frequency occurred in 2005, when eight heat waves were detected.

Heat and cold waves were detected in most of the years of the period examined. There were only seven years $(1963,1967,1971,1972,1975,1976$, and 1976) in which no heat waves were detected, while in the case of cold waves there were only two years (1968 and 1989) without the occurrence of the defined extreme event. Regarding intense heat waves, their frequency distribution shows similar behavior as for all heat waves, but with a lower number of cases. The annual average of cold waves is greater than that of heat waves in each of the regions under study, because extreme warm anomalies often have shorter than two-day episodes, or they do not extend to both DMATA and DMITA.

The months with the lowest frequency of heat waves are January, February, and November while those with the highest number of heat waves are May and June, followed by April and August. The highest frequency of intense heat waves occurred in May and June. In the rest of the months, the number of intense heat waves was very low.

Cold waves were detected in each month of the year with a fairly uniform distribution, in contrast with the seasonal distribution of heat waves. Months with the highest number of cold waves were March, May, June, and October and months with the lowest number of cold waves were July, August, and April. Note that this seasonal distribution is quite different from the classic one (i.e., heat waves in summer and cold waves in winter). The month with the highest number of intense cold waves is September, while no intense cold wave was detected in August and November.

The trend analysis revealed the existence of a statistically significant increasing trend of heat wave frequency ( 0.56 heat waves per decade) and a statistically significant decreasing trend of cold wave frequency ( 0.54 cold waves per decade), which confirms that the global warming has important effect on the changes of extreme temperature events in the examined area.

\section{Acknowledgements}

This work was developed within the framework of the CGL2009-08565 research project funded by the Ministerio de Ciencia e Innovación de España (Spanish Ministry of Science and Innovation). The authors thank Spain's Agencia Estatal de Meteorología for providing the data used in this study.

\section{References}

Baldi M., G. Dalu, G, Maracchi, M. Pasqui and F. Cesarone, 2006. Heat waves in the Mediterranean: A local feature or a larger-scale effect? Int. J. Climatol. 26, 1477-1487.

Brunetti M., M. Maugeri and T. Nanni, 2001. Changes in total precipitation, rainy days and extreme events in northeastern Italy. Int. J. Climatol. 21, 861-871.

Changnon D., M. Sandstrom and C. Schaffer, 2003. Relating changes in agricultural practices to increasing dew points in extreme Chicago heat waves. Clim. Res. 24, 243-254.

Domonkos P., J. Kyselý, K. Piotrowicz, P. Petrovic and T. Likso. 2003. Variability of extreme temperature events in South-Central Europe during the 20th century and 
its relationship with large-scale circulation. Int. $J$. Climatol. 23, 987-1010.

DeGaetano A. T. and R. J. Allen, 2002. Trends in twentieth-century temperature extremes across the United States. J. Climate 15, 3188-3205.

Griffiths G. M., M. J. Salinger and I. Leleu, 2003. Trends in extreme daily rainfall across the south Pacific and relationship to the south Pacific convergence zone. Int. J. Climatol. 23, 847-869.

IPCC, 2013. Climate Change 2013: The Physical Science Basis. Contribution of Working Group I to the Fifth Assessment Report of the Intergovernmental Panel on Climate Change (T. F. Stocker, D. Qin, G.-K. Plattner, M. Tignor, S. K. Allen, J. Boschung, A. Nauels, Y. Xia, V. Bex and P. M. Midgley, Eds.). Cambridge University Press, Cambridge and New York, $1535 \mathrm{pp}$.

Jones P. D. and M. Hulme, 1996. Calculating regional climate time series for temperature and precipitation: Methods and illustrations. Int. J. Climatol. 16, 361-377.

Khaliq M. N., A. St-Hilaire, T. B. M. J. Ouarda and B. Bobée, 2005. Frequency analysis and temporal pattern of occurrences of southern Quebec heatwaves. Int. J. Climatol. 25, 485-504.

Klein A. M. G. and G. P. Können, 2003. Trends in indices of daily temperature and precipitation extremes in Europe, 1946-99. J. Climate 16, 3665-3680.

Kyselý J., 2002. Temporal fluctuations in heat waves at Prague-Klementinum, the Czech Republic, from 1901-97, and their relationships to atmospheric circulation. Int. J. Climatol. 22, 33-50.

Kyselý J. and M. Dubrovský, 2005. Simulation of extreme temperature events by a stochastic weather generator effects of interdiurnal and interannual variability reproduction. Int. J. Climatol. 25, 251-269.

Labajo J. L., Q. Martín, A. Piorno, A. L. Labajo, C. Morales and M. T. Ortega, 2004. Primeros resultados del análisis del comportamiento de los valores extremos de la presión atmosférica, a nivel del suelo, en Castilla y León. In: El clima entre el mar y la montaña (J. C. García Codrón, C. Diego, P. Fernández de Arróyabe, C. Garmendia and D. Rasilla, Eds.). Publicaciones de la Asociación Española de Climatología, Santander, pp. 313-321 (Serie A, 4).

Labajo J. L., A. L. Labajo, Q. Martín, A. Piorno, C. Morales and M. T. Ortega, 2006. Análisis del comportamiento reciente de los valores extremos de temperatura en la zona Madrid-Castilla La Mancha. In: Clima, sociedad $y$ medio ambiente (J. M. Cuadrat, M. A. Saz, S. M.
Vicente, S. Lanjeri, M. De Luis and J. C. González, Eds.). Publicaciones de la Asociación Española de Climatología, Santander, 157-165 (Serie A, 5).

Labajo J. L., Q. Martín, A. L. Labajo, A. Piorno, M. T. Ortega and C. Morales, 2008. Recent trends in the frequencies of extreme values of daily maximum atmospheric pressure at ground level in the central zone of the Iberian Peninsula. Int. J. Climatol. 28, 1227-1238.

Labajo A. L and J. L. Labajo, 2010. Evolución de la frecuencia anual de los días extremadamente fríos en época fría, entre 1961 y 2003, en la Meseta Central española In: Clima, ciudad y ecosistemas (F. Fernández, E. Galán and R. Cañada, Eds.). Publicaciones de la Asociación Española de Climatología, Santander, pp. 151-159 (Serie A, 7).

Labajo J. L., A. L. Labajo, M. Egido, Q. Martín, C. Morales and M. T. Ortega, 2012. Analysis of the maximum daily temperature evolution on the Spanish Central Plateau. Atmósfera 25, 235-252.

López-Díaz J. A, 2004. Análisis de tendencias en olas de calor a partir de series largas de temperatura. In: $E l$ clima entre el mar y la montaña (J. C. García Codrón, C. Diego, P. Fernández de Arróyabe, C. Garmendia and D. Rasilla, Eds.). Publicaciones de la Asociación Española de Climatología, Santander, pp. 347-354 (Serie A, 4).

Manton M. J., P. M. Della-Marta, M. R. Haylock, K. J. Hennessy, N. Nicholls, L. E. Chambers, D. A. Collins, G. Daw, A. Finet, D. Gunawan, K. Inape, H. Isobe, T. S. Kestin, P. Lefale, C. H. Leyu, T. Lwin, L. Maitrepierre, N. Ouprasitwong, C. M. Page, J. Pahalad, N. Plummer, M. J. Salinger, R. Suppiah, V. L. Tran, B. Trewin, I. Tibig and D. Yee, 2001. Trends in extreme daily rainfall and temperature in Southeast Asia and the South Pacific: 1961-1998. Int. J. Climatol. 21, 269-284.

Nogueira P. and E. Paixão, 2008. Models for mortality associated with heat waves: Update of the Portuguese heat health warning system. Int. J. Climatol. 28, 545562.

Ortega M. T., C. Morales, J. L. Labajo, A. L. Labajo, A. Piorno and Q. Martín, 2006. Tendencias recientes en las frecuencias de los valores extremos de temperatura en la región de Castilla y León. In: Clima, sociedad $y$ medio ambiente (J. M. Cuadrat, M. A. Saz, S. M. Vicente, S. Lanjeri, M. De Luis and J. C. González, Eds.). Publicaciones de la Asociación española de Climatología, Santander, pp. 251-259 (Serie A, 5).

Plummer N., M. J. Salinger, N. Nicholls, R. Suppiah, K. J. Hennessy, R. M. Leighton, B. Trewin, C. M. Page 
and J. M. Lough, 1999. Changes in climate extremes over the Australian region and New Zeland during the twentieth century. Climatic Change 42, 183-202.

Robinson P. J, 2001. On the definition of a heat wave. $J$. Appl. Meteor. Clim. 40, 762-775.

Salinger M. J. and G. M. Griffiths, 2001. Trends in New Zealand daily temperature and rainfall extremes. Int. J. Climatol. 21, 1437-1452.
Sneyers R., 1975. Sobre el análisis estadístico de las series de observaciones. Nota Técnica 143, OMM- 415. Organización Meteorológica Mundial, Ginebra, 192 pp. Zhou Y. and Ren G., 2012. Change in extreme temperature event frequency over mainland China, 1961-2008. Clim. Res. 50, 125-139. 